\title{
The Church as the Body of Christ
}

Prof. J. J. J. van Rensburg

The significance of the metaphor in 1 Cor $12: 27$ for the assessment of the New Testament teaching on the unity of the church.

Different metaphors depicting one or more facets of the church are used in the New Testament. An interpretation of the different metaphors will contribute to the assessment of the New Testament teaching on the unity of the church.

This chapter envisages to make such an interpretation of the metaphor "you are the body of Christ" in 1 Cor $12: 27$. This isolation of the metaphor, however, is by no means a reconstruction of the metaphor into a model; it is merely a delimitation to facilitate the interpretation.

\section{INTERPRETING A METAPHOR}

The metaphor "you are the body of Christ" consists of a tenor (you, i.e. the Church) and a vehicle (the body of Christ) (cf. Grabe 1984:12).

When interpreting a metaphor it is important to keep in mind that a metaphor is no mere comparison, but that there is always an element of tension (Combrink 1986:226). The metaphor is no stylistic substitution; it is a redescription of reality (Clowney 1984:75), a fusion of two horizons (Combrink 1986:226), it - as Clowney (1984:103) puts it - " draws together two dissimilar contexts", and therefore forces the interpreter to rethink reality and his view of both contexts.

Clowney $(1984: 103)$ is right when he stresses that metaphors are to be understood and interpreted in their context. When interpreting a metaphor, it is imperative that the imagination "is not freed to re-direct the metaphorical expression into other channels, but to pursue the depths of the biblical analogy" (Clowney 1984:102). For the interpretation of the vehicle it is necessary that its original horizon be regained if it is to serve its valid metaphorical function (Clowney 1984:104). Therefore the first century understanding of "body" and "body of Christ" must be used as the grid in interpreting the meaning of the vehicle (in its original context), and its significance in the context of present day culture.

Therefore the contexts of the metaphor "you are the body of Christ" play a most important role in the interpretation of the metaphor. This pertains to the immediate context, but also the wider context of the progressive history of redemption.

Only after the significance for the New Teslament teaching on the unity of the church has been determined in this way, can the significance of the revelation for the present day church be explored successfully. 


\section{INTERPRETATION OF 1 CORINTHIANS $12: 12-31$}

\subsection{The metaphor proper}

In the pericope 1 Cor $12: 12-31$ the metaphor is used in a compounded way. Explicit use of the metaphor proper is found in 1 Cor $12: 27$ :

27

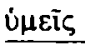

$$
\begin{aligned}
& \square \delta \varepsilon \varepsilon \sigma \tau \square \sigma \bar{\omega} \mu \alpha \\
& \square \kappa \alpha i(\underline{\varepsilon \sigma \tau \varepsilon)} \square \mu \varepsilon \dot{\varepsilon} \lambda
\end{aligned}
$$

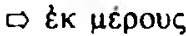

you

$$
\begin{aligned}
& \square \text { are } \square \text { the body } \\
& \square \text { and are } \square \text { of Christ } \\
& \square \text { members }
\end{aligned}
$$

It is necessary to make a careful analysis of the pericope in order to assess the relevancy of the metaphor for the New Testament teaching on the unity of the church, since the whole pericope is an elaboration of this metaphor.

2.2 An analysis of the structure of the argument of the pericope v. 12: the basic statement, introducing the vehicle of the metaphor The basic statement is made in v. 12: "The body is a unit, though it is made up of many parts; and though all its parts are many, they form one body. So it is with Christ" (New International Version). Although the metaphor proper only occurs in v. 27, the vehicle of the metaphor (i.e. "the body" and "Christ") is introduced in this introductory verse. There is as yet no genitive construction between "body" and "Christ", but it is already evident from the contents that "body" and "Christ" are in some way connected.

v. 13: introduction of the tenor of the metaphor

In v. 13, introduced by the particle gar, the author not only states his reason for using the "body" symbol ("for we are all baptised by one Spirit into one body"), but he also introduces the tenor of the metaphor, viz. "we", i.e. all the believers, "whether Jews or Greeks, slave of free".

Vv. 14-19: the reason for the diversity within a body

In v. 14 the reason for the diversity within a body is stated: "For the body is not made up of one part but of many." In vv. 15 and 16 the author states the implication of this diversity within the body: the fact that the body is made up of different parts, does not imply that any one part ever ceases to be part of the body.

Verses 17-19 give three reasons for the statement that the body is made up of many parts: v. 17 argues that if there were not different parts, the body would not be able to perform all its functions; v. 18 reminds of the fact that God created and arranged every single part of the body, and that in doing this He answers to no-one except himself; in v. 19 the author summarises his argument by stating - by way of a rhetorical question - that if the body consisted of one part only, it would not be a body.

\section{Vv. 20-24a: the unity of a body in spite of internal diversity}

Verses 20-24a form a new sub-section. In $v$. 20 the author recapitulates the basic statement of v. 12 (cf. Robertson \& Plummer 1967:274), focusing on the fact that the body, in spite of internal diversity, is one. He then gives two implications of this unity: in $v$. 21 he argues the inter- 
dependency of the parts: since all the parts benefit when the body functions properly, the different parts need one another.

In vv. 22-24a he points to the fact that the different parts require a differentiated treatment from the "owner" of the body : exactly because the body functions as a unit, the "owner" is obliged to see to it that all the parts of the body function properly. This entails that he gives special attention and care to those members that need it in order to perform their functions.

Vv. 24b-26: the combination of the parts of the body

Vv. 24b-26 form another sub-section, parallel to vv. 21-24a. This is again a recapitulation of the basic statement of $\mathrm{v} .12$, but this time focussing on the combination of the different parts of a body. In v. 24b he states that God has combined the different parts of the body, there is therefore no room for a single part to object to its role and function within the body; the part did not get its role by mere chance, but by divine providence. and - the author adds - God did not do this haphazardly: he gave greater honour to the parts that lacked it.

In v. 25 God's purpose with this specific combination of the parts of a body is stated: "so that there should be no division in the body, but that the parts should have equal concern for each other". The result when the many parts of a body are thus combined, is stated in v. 26: "If one part suffers, every part suffers with it; if one part is honoured, every part rejoices with it".

\section{Vv. 27-31: application of the argument to the Corinthian church}

Verses 27-31 form the last sub-section of this pericope. The argument of vv. 12-26 is applied to the Corinthian church. In v. 27a the vehicle and the tenor of the metaphor, already introduced respectively in $v .12$ and v. 13, are identified, and the metaphor proper is stated: "you are the body of Christ". Immediately the theme of the preceding is applied: "and each one of you is a part of it" (cf. Schneider 1967:596-7). Then the author adds the vertical dimension, as he had done in v. 18 and again in v. 24b: "God has appointed you in the church". When interpreted in terms of the metaphorical context, the author wants to convince his readers to accept two things: that each one of them is part of the one body of Christ; and that they must acknowledge the fact that God himself assigned their role and function in the body to them.

In v. 28b Paul lists the different "parts of the body", the different roles different members are obliged to fulfil. By way of a number of rhetorical questions he implies in vv. 29 and 30 that all the members can not perform the same functions.

Verse 31 is a conclusive exhortation: "Therefore eagerly desire the greater gifts."

$\Lambda$ synopsis of the structure of the argument

The following synopsis gives an overview of the flow of thought in 1 Cor $12: 12-31$ according to the preceding interpretation. The thought structure has been partly symbolised by using blocks and connecting lines. The text itself is put in the block. The connecting lines indicate the portion of the preceding text with which the present block is related, and the relation is defined on the line immediately above the block:; 
The basic statement of the metaphor

v. 12. The body is a unit, though it is made up of many parts; and though all its parts are many, they form one body. So it is with Christ.

The reason for using the "body" symbol, introducing the tenor of the metaphor

v. 13. For we are all haptised by one Spirit into one body - whether Jews

or Greeks, slave or free - and we are all given the one Spirit to drink.

The reason for the diversity in body

v. 14. For a body is not made up of one part but of many.

Implication of the diversity within a body: every part is part of the body

v. 15. If the foot should say, "Because I am not a hand, I do not belong to the body", it would not for

- v. 16. that reason cease to be part of the body. And if the ear should say, "Because I am not an eye, I do not belong to the body", it would not for that reason cease to be part of the body.

Three reasons for the fact that a body is made up of many parts

v. 17. If the whole body were an eye, where would the sense of hearing
be? If the whole body were an ear, where would the sense of smell be?
v. 18 . And in fact God has arranged the parts in the body, every one
of them, just as he wanted them to be.
v. 19 . - If they were all one part, where would the body be?

First recapitulation of the basic statement in v. 12: unity in spite of internal diversity

v. 20. As it is, there are many parts, but one body.

First implication of the unity of a body: interdependency of the parts

v. 21. The eye cannot say to the hand, "I don't need you!" And the head cannot say to the feet, "I don't need you!"

Second implication of the unity of a body: differentiated treatment of the parts

On the contrary:

v. 22. those parts of the body that seem to be weaker are indispensable

v. 23. $\star$ and the parts that we think are less honourable we treat with special honour

$\star$ and the parts that are unpresentable are treated with special modesty. while

v. 24. our presentable parts need no special treatment.

Second recapitulation of the basic statement in v. 12: the combination of the parts

v. 24b. But God has combined the parts of the body, giving greater honour to the parts that lacked it.

God's purpose with this specific combination of the parts of a body

v. 25. So that there should be no division in the body, but that the parts should have equal concern for each other.

Implication of the fact that the many parts of a body are thus combined

v. 26. If one part suffers, every part suffers with it; if one part is honoured, every part rejoices with it. 
The argument of $w$. 12-26 applied to the Corinthian church

The methaphorical statement, identifying the tenor and the vehicle

v. $27+28$ a. Now you are the body of Christ, and each one of you is a part of it, and God has appointed you in the church.

Application of the argument of $\mathrm{w}$. 12-26: The different functions of the different members

v. 28b. (God appointed the following): First of all apostles, second prophets, third teachers, then workers of miracles, also those having gifts of healing, those able to help others, those with gifts of administration, and those speaking in different kinds of tongues.

v. 29. Are all apostles? Are all prophets? Are all teachers? Do all work miracles? v. 30 . Do all have gifts of healing? Do all speak in tongues? Do all interpret?

Conclusive exhortation

v. 31. Therefore eagerly desire the greater gifts.

2.3 Interpretation of the tenor and the metaphor

It is quite clear from the context who the tenor, you, is: they are those who have been appointed in the church by God (v. 28a), who have been "baptised by one Spirit into one body", and "who are given the one Spirit to drink", "whether Jews or Greeks, slave or free" (v. 13). In 1 : 2 Paul identifies his addressees as "the church of God in Corinth. . . . those sanctified in Christ Jesus and called to be holy, together with all those everywhere, who call on the name of our Lord Jesus Christ." The you are therefore the faithful, the believers, the church in Corinth.

\subsection{Interpretation of the vehicle of the metaphor}

The vehicle, the body of Christ, must be interpreted against its historical scriptural setting.

\subsubsection{The origin of the figure}

Clowney (1984:85) remarks that scholars have expended more effort in seeking the origins of this figure than in exploring its meaning. And after all the effort almost every part of Paul's religious and cultural background has been isolated as the source of his use of this body figure.

Clowney's own argument (1984:85-86), after observing Paul's use of the figure, is convincing. He finds the key to Paul's use of the metaphor "body of Christ" in the principle of covenantal representation as it is applied to the literal body of Christ. Ridderbos (1975:375-376) underscores this view. Clowney $(1984: 86)$ is right when he infers from Eph $2: 13-16$ that there is a close connection in Paul's mind between the physical body of Christ and the church as the body of Christ.

Viewed in context of the progressive history of redemption this metaphor could only have been shaped after the death, resurrection and ascension of the Lord. His physical body had to be known before it could be used in a metaphor. Schweizer (1971:1074) convinces when he argues that the present metaphor and the metaphor "the people of God" are at root one, but that "the body of Christ" emphasises the present character of the saving act of God. "The people of God" emphasises the way which leads 
from the saving act on into the present and the future. Ridderbos (1975:395) speaks of the "body of Christ" as the christological concentration of the "people of God".

\subsubsection{The vehicle in 1 Cor 12}

No final and exhaustive interpretation possible

Since this is a metaphor and no simple word-substitution, it is not possible to simply paraphrase the central meaning of this metaphor in an understandable way. Clowney (1984:96) rightly says that "to draw out the fullness of meaning may prove to be an ongoing process." Therefore this metaphor (as do other metaphors) compels the interpreter to constantly revise his conclusions, and in so doing leads him into further understanding produced by the power of its truth (Clowney 1984:97). This attempt to interpret the metaphor, although tentative, also calls for a continuing revision of conclusions, both past and present.

Mixture of reality and redescription

In vv. 12-26 (with the exception of v. 13) Paul gives an explication of the vehicle of the metaphor he uses in v. 27. He explains the body figure from the beginning.

As often happens in metaphorical language it is also here not always clear whether Paul has the physical body (any physical body or Christ's physical body) in mind, or whether he is already speaking figuratively of the church as body (of Christ). Already in the introductory verse this interweaving is evident : he is comparing a physical body with Christ (kathaper to soma ... houtos kai ho Christos), and he immediately focuses the attention on the issues he will dwell on: the unity of the body, in spite of the fact that it is made up of many parts (cf. Schweizer 1971: 1071).

Verse 13 is very important for the development of the argument. It defines the problem that Paul will be addressing in this pericope, viz. the relation between the diversity of the "we" (Greeks and Jews, and slaves and free men) who have been baptised by the one Spirit and have all been given the one Spirit to drink. He hints at the solution of the problem when he mentions that the baptism by one Spirit was done into one body. In this way he in passing alludes to the metaphor proper of v. 27, before explaining the make-up of a physical body in vv. 14-26.

One other remark concerning the unity of the church must be made: in $\mathrm{v} .13$ the way in which a person becomes a member of the body is stated, viz. baptism by the Spirit. This baptism initiates one into the body of Christ (Floor 1979:58) and is therefore a sign of the unity of the body (cf. Fisher 1975:199).

\section{Diversity in body and church}

Verse 14 states that diversity within a body is inevitable: a body is not made up of one part but of many.

In vv. 15 and 16 Paul is speaking figuratively. It is clear that he is already directing the argument towards a problem in the Corinthian church: some members deemed their own role in the church to be inferior. It seems as if they thought some roles in the church to be so inferior that they were not essential to the existence of the church, and that therefore the concerned part is not really part of the church. It is not only the more 
prominent parts of the body (the hand or the eye) that constitutes the body. In vv. 15 and 16 Paul states - by using the body figure that every part of the body is and stays part of the body, irrespective of its function in the body or its own appraisal of this function

In vv. 17-19 Paul emphasises the fact that a (physical) body is necessarily made up of many parts. If that was not the case, the body would not be able to perform all its functions, such as hearing, seeing. smelling (v. 17). To think of a body as consisting of one part, is a contradiction (v. 19). With the rhetorical questions in vv. 29 and 30 Paul explicitly applies this figure to the church: in the church all the gifts have to exist and work.

In v. 18 and again in vv. $24 \mathrm{~b}-26$ the author stresses the fact that there is no haphazard arrangement and combination of the parts of a (physical) body; there is a very definite arrangement and combination, and this was done by God. No part of a body can therefore despise its place and role in the body; God himself arranged the parts of the body. giving greater honour to the parts that lacked it.

Paul himself explicitly applies this figure of the arrangement and combination of the parts to the church: after stating (in v. 27) that "you are the body of Christ, and each one of you is a part of it", he emphatically adds: "and God has appointed you in the church".

Unity in spite of internal diversity

In vv. 20-24a Paul emphasises the fact that the body is and stays a unity in spite of internal diversity. After stating the fact that the body has many parts, but that this unity of the body necessarily implies that the parts of the body are inter-dependent : the eye needs the hand to function properly, and the head the feet (v. 21). This argument is not explicitly taken up again in vv. 27-31, but the application to the church is evident: all the members in the church need one another

Verses 22-24a still dwell on the topic of the unity of the body, but now from the viewpoint of the owner of the body. The owner of the body must see to it that all the parts of the body are in a position to function, otherwise the body itself will not function properly. He knows that the seemingly weaker parts are indispensable (v. 22): he treats the parts deemed less honourable, with special honour; and the unpresentable parts he treats with special modesty (vv. 22, 23). The presentable parts are in no need of special treatment in order to function (v. 24a).

This argument on the differentiated treatment of the different parts of the body is not taken up again in vv. 27-31. In v. 24b God is mentioned as giving greater honour to the parts that lack it, this, however. still pertains to the physical body in the first place (cf Fisher $1975: 2(14)$. In the context of the whole pericope and in the wider context of the Bible. the meaning is clear: God, or more specific, Christ is the "owner" of his body, the church. He wants his body to tunction properly. and theretore He differentiates his treatment of the parts, and this He does in the way explained in vv. 22-24a.

What is stated in v. 25 also has important implication for the unity of the church. Verse 25 mentions God's purpose with his specific combination of the parts of a body: "so that there should be no division in the 
body, but that the parts should have equal concern for each other". The result of such a combination of parts is that every part suffers when one part suffers, and that every part rejoices with one part when it is honoured (v. 26). It is therefore clear that the internal diversity does not and should not lead to a disruption of the unity, and that this is the case inter alia because God combined the parts of the body in the way he did.

\section{SIGNIFICANCE FOR THE NEW TESTAMENT TEACHING ON THE UNITY OF THE CHURCH}

\subsection{The unity is indicative and imperative}

Ridderbos (1975:369) is right when hy says that Paul uses this metaphor with a clear paraenetic purpose. It is therefore no mere statements which he makes, but an imperative which rests on the indicative.

\subsection{The unity of the church, local and universal}

The unity of the church signifies both the internal unity of a local church (the intra-unity of the church), as well as the unity between different local churches (the inter-unity of the church). Snyman (1949) and Schmidt (1965:506-509) have convincingly argued, after studying the use of the word ekklesia, that revelation pertaining to the local church, is also applicable to the universal church (cf. Martin 1984:31). Therefore, what is said on an intra-level of the unity of the church, applies also to the inter-level. On the intra-level the "parts of the body" are the different members of the church, and on inter-level the "parts of the body" are the different local churches. Both on intra as well as inter-level the church is - speaking in terms of the present metaphor - "the body of Christ"' (cf. Grosheide 1957:334).

The fact that there are presently different denominations (as collections of local churches) finds no parallel in the New Testament. Whether the metaphor is also applicable to the inter-relations of present day denominations, is a matter which needs further research.

\subsection{A sign of the unity of the church}

In $v .13$ baptism by the Spirit is stated as the way in which a person becomes member of the body. This baptism can therefore be regarded as a sign of the unity of the church, both on intra-unity level (cf. Van Wyk 1987:19), as well as inter-unity level.

\subsection{Earthly distinctions are superseded in the one body}

From v. 13 it is clear that when a person has become a member of the body of Christ, this membership supersedes both cultural/ethnic distinctions (Jews or Greeks) as well as social distinctions (slave or free) (cf. also Bosch 1979:1-2).

This statement also holds true for the universal church: the cultural/ ethnic or social uniqueness of a church is superseded in the unity of the church.

\subsection{An "inferior" role does not cancel membership}

However small the role that a member play 3 in the church, that member stays a member of the church, in the same way as each part of the body is and stays an essential part of the body (vv. 15 and 16). 
On the inter level this means that a local church is and stays part of the church, however small or insignificant its role and furction in the church.

\subsection{Diversity within the church is essential for its functioning}

Verses $1^{\prime} ;$ and 19 show that without different members per for ming different functions and having different abilities, the church can not function properly. Just as all the functions of a body are not performed by one part of the body, in the same way all the functions God demands from the church, are not and can not be performed by one member. It pleased God - speaking metaphorically to make the one member the eye of the body, the other the ear, the other the nose, etc. Only when this diversity exists, the body can function properly.

These statements concerning the local church can be transposed to the universal church: different local chur ches performing different functions and having different abilities at e ersential for the pruper function ing of the church. In the same way as all the functions of a body are not performed by one part of the body, all the functions God demands from the church are not and can not be performed by any single local church. The body of Christ is made up of different churches, each with a specific role. This diversity is essential for the functioning of the body

Any attempt of assigning identical roles to all members in a local church (and to all the local churches), tampers with the essential diversity of the church, and this will result in a disfigurement of the body of Christ and the diminishing of its ability to function properly. Van Aarde. (1987:325-351) is right when he describes the beginnings of the church as a history of reconciliating diversity. The unity never means uniformity. The following statement by Schlink (1969:50) aptly underscores the point:

we perceive the historical necessity for many concrete forins of proclamation, worship, dogmatic statements, etc. In these differences we also recognise one-sided aspects, inadequacies and corrections . . But we also perceive that many one-sided aspects, inadequacies, and corrections complement each other and form an integral whole, despite the divisions. We perceive that God has not ceased to regard the churches as a whole, despite their separation ...

\subsection{The appointment in the church is made by God}

From v. 18 , read with v. 28 , it is clear that believers are appointed in the chui ch by God. Their role and function are not to be decided horizon!tally, but vertically. And if a member desires another role and function. this should be petitioned from Sod (vv. 28 and 31) (cf. Grosheide 1957:339).

'The same applies to the church on inter-level: churches are allotted their place and role in the body by God. The fact that the role of a church is decided by God, does not imply that the church can not strive for an other role. This should, however, be done in subjugation to the will of God.

\subsection{Inter-dependency of members neccessitates unity}

The members of the church are inter-dependent (v. 21) and need each 


\section{In die Skriflig}

other; the one member cannot function without the support of the others. This mutual support of the different members can only take place within the unity of the body, the church. Despite the diversity the unity of the church therefore remains (v. 20). No member can function properly without being part of the one body.

The same applies to the church on inter-level: the different churches (and denominations) are interdependent. The one church can not function without the support of the other. The unity of the body is a prerequisite for this mutual support to take place.

3.9 Christ differentiates in his ireatment of the members of the church Christ is the owner of his body, the church. Christ wants his body to function properly. This can only happen when all the parts function properly. Therefore the owner gives special treatment to the members of the church, who, because of their role or constitution, are in the greatest danger of not functioning properly. In metaphorical language these members are those that seem weaker (but are indispensable) (v. 22 ), those that are deemed less honourable (v. 23a) and those that are unpresentable (v. 23b). The other members need no special treatment. This differentiation is done for the sake of the body, all the members of the church.

What has been said pertaining to the local church, is also applicable to the universal church: Christ, the head of the church, differentiates his treatment of churches, giving special treatment to those that need it to function properly. This is not an injustice to the other churches; only when the "weaker", "less honourable" and "unpresentable" churches are functioning properly, the unity of the body persists, and do all the member-churches get the full benefit of this functioning in unity. The differentiation thus actually benefits the whole body, all the members.

\subsection{Outward manifestation of the unity of the church}

The fact that there is no division in the church must become evident (Ridderbos 1975: 394, Van Wyk 1987:6-7 and Runia 1968:58). From v. 25 it is clear that this happens through the equal concern of the members for each other. The existence of the unity also becomes apparant if every member of the church suffers when one member suffers, and if every member rejoyces when one member is honoured. This equal mutual concern serves as a touchstone for the existence of a unified church.

Again this is also applicable to the church on inter-unity level: on the one hand the presence of equal concern of churches for each other testifies to the unity of the church. The absence of such mutual concern, on the other hand, testifies to a lack of acknowledgement of the unity of the church.

\subsection{An organic unity}

The metaphor points to the character of the unity: it excludes any idea of a mechanical unity. The body is an organism (cf. Van der Walt 1976:54) : this implies that the unity is primary. It is not a result of the composition of different parts. It is a living unity which is more than the constituting parts.

This character of the unity applies both to the local church (the unity 
of the members), as well as the universal church (the unity of the churches (or denominations)). The body of Christ is a living unity, and is not dependent for its existence on the different members; it exists as a living unity, because it exists in and because of Christ, and not vice versa (cf. Floor 1967:43 and König 1979:91).

When this is accepted, however much the unity is and must be sought, the process is never characterised by a feverish activity as if the existence of the body of Christ is at stake. The unity must be desired, but with peace of mind and tranquility because of the conviction that the unity of the body of Christ does exist (cf. Runia 1968:52,53); it is not a question of bringing this unity about, but of realising and experiencing it. This, however, should never be misunderstood as a reason for complacency; rather the undeniable reality of the indicative, places an enormous pressure on the imperative (cf. Runia 1968:63)

\section{A SUMMARY OF THE SIGNIFICANCE OF THE METAPHOR FOR THE NEW TESTAMENT TEACHING ON THE UNITY OF THE CHURCH}

The significance of the metaphor "you are the body of Christ" for the New Testament teaching on the unity of the church is the following:

1. The unity of the church is an indicative and an imperative

2. The revelation pertaining to the unity of the church applies to both the local and the universal church

3. Baptism by the Spirit is a sign of the unity of the church

4. Earthly distinctions are superseded in the church

5. An inferior role does not cancel membership of the church

6. Diversity within the church is essential for its functioning

7. The appointment in the church is made by God

8. The inter-dependence of the members of the church neccessitates unity of the church

9. Christ differentiates in his treatment of members of the church

10. The unity of the church must manifest itself outwardly

11. The unity of the church is of an organic and not a mechanical character

12. Further research must determine how the metaphor is applicable to the inter-relations of present day denominations.

\section{BIBLIOGRAPHY}

Barnard , A C. 1971. Die lewende kerk volgens die Skrif. Die Nederduitse Gereformeerde Teologiese Tydskrif 12, 261-266.

Berkhof, H [sa]. Gods éne kerk en onze vele kerken. Nijkerk: G F Callenbach nv.

Best, E. 1955. One body in Christ: a study in the relationship of the church to Christ in the epistles of the apostle Paul. London: SPCK.

Bosch, D J. 1979. Die "nuwe gemeenskap" rondom Jesus van Nasaret, in Meiring \& Lederle 1979:1-5.

Botha, C J. 1979. Calvyn se siening oor die eenheid van die kerk, in Meiring \& Lederle 1979:32-43.

Cerfaux, L. 1959. The church in the Theology of St. Paul, translated by G Webb \& A Walker. New York: Herder \& Herder.

Clowney, E P. 1984 Interpreting the biblical models of the church: a hermeneutical deepening of ecclesiology, in Carson, DA (ed), Biblical interpretation and the church: text and context, 64-109. Exeter: The Paternoster Press. 
Coetzee, J C. 1956. Volk en Godsiolk in die Nuwe Testament Potchefstroom: Pro Rege. Combrink, B. 1986. Perspektiewe uit die Skrif, in Kinghorn J (ed), Die NG Kerk en Apartheid. 211-234. Johannesburg: Macmillan South Africa.

Du Plessis. I J. 1962. Christus as hoof van kerk en kosmos. Groningen: VRB Kleine der A 3-4.

Fisher. F. 1975. Commentary on $1 \& 2$ Corinthians. Waco: Word Books

Floor, L. 1967. Die formule "in Christus" by Paulus. ThM-thesis, Potchefstroom University for Christian Higher Education.

Floor. L. 1975. Hy wat met die Heilige Gees doop. Pretoria: NG Kerkboekhandel

Gereformeerde Kerke in Suid-Afrika. 1988. Agenda van die drie-en-veertigste sinode te Potchefstroom op 5 Januarie 1988 en volgende dae. Potchefstroom: Die Gereformeerde Kerke in Suid-Afrika.

Grabe, I 1984. Aspekte van poetiese taalgebruik: teoretiese verkenning cn to'passing. Potchefstroom: Sentrale Publikasies.

Groenewald, E P. 1971. Die eerste brief aan die Korinthiers. Kaapstad: NG Kerkuitgewers.

Grosheide, F W. 1957. De eerste brief aan de kerk te Korinthe. Kampen: J H Kok nv

Houtepen. A 1979. Koinonia and consensus: towards communion in one faith. The Ecumenical Review 31, 60)-63.

Konig. A. 1979. Modelle van kerkeenheid, in Meiring \& I ederle 1979:89-101

Martin. R P 1984. The Spirit and the congregation: studies in 1 Corinthians 12-15. Crand Rapids: Eerdmans.

Meiring. P \& Lederle, H I (reds). 1979. Die cenheid ran die kerk. Kaapstad: Tafelberg

Moore, W E. 1964. One baptism. New Testament Studies 10, 504-510.

Ridderbos. H. 1975. Paul, an outline of his theology, translated by J R de Witt. (irand Kapids: Eerdmans.

Robertson. A \& Plummer, A [1914]. 1967. A critical and exegetical conmentary on the first epistle of St Paul to the Corinthians. Edinburgh: T \& T Clark

Runia, K. 1968. Reformation today. London: The Banner of Truth Trust

Schlink. E. 1969. The unity and diversity of the church, Groscurth, R (ed). What unity implies: six essays after Uppsala, 33-51. Geneva: World Council of ('hurches.

Schmidt, K L. 1965. sv ekklesia. TDNT.

Schneider, J. 1967. sv soma. TDNT

Schweizer, E. 1971. sv swma. TDNT

Snyman. W J. 1949. Die gebruik van die woord "kerk" in die Nuwe Testament. Potchefstroom: CJBF.

Spoelstra. B. 1986. Het ons kerkwees in strukture gestol? Hervormde Teologiese Studies 42. 94-109.

Theron. P F . 1979. Die kerk as eskatologiese teken van eenheid, in Meiring \& I rederle 1979:6-13.

Van Aarde. A G. 1987. Gedagtes oor die begin van die kerk 'n geskiedenis van versoenende verskeidenheid. Hervormde Teologiese Studies 43, 325-351.

Van der Walt. J J. 1976. Christus as Hoof van die kerk en die presbiteriale kerkregering Potchefstroom: Pro Rege.

Van Wyk, J H. 1986. Bavinck oor kerkeenheid. In die Skriflig 20, 43-44

Van Wyk J H. 1986a. Kerklike kontak oor kultuurgrense heen. Die Almanak van die Gereformeerde Kerke in Suid-Afrika 112, 215-219.

Van Wyk. J H. 1987. Kerkeenheid: 'n perspektief op die verhoudinge in die Gereformeerde Kerke in Suidelike Afrika. Paper presented at a meeting of the Gereformeerde Teologiese Vereniging. Pretoria.

Visser't Hooft, W A. 1956. The renewal of the church. Philadelphia : the Westminster Press.

Wansbrough, H. 1968. Theology in St. Paul Notre Dame: Fides Publishers 